\title{
Durability of Concrete Structures with Sugar Cane Bagasse Ash
}

\author{
R. Berenguer $\mathbb{D}^{1,2}$ N. Lima, ${ }^{3}$ A. C. Valdés, ${ }^{4}$ M. H. F. Medeiros, ${ }^{4}$ N. B. D. Lima $\mathbb{D}^{1}{ }^{1}$ \\ J. M. P. Q. Delgado $\left(\mathbb{1},{ }^{5}\right.$ F. A. N. Silva, ${ }^{6}$ A. C. Azevedo, ${ }^{5}$ A. S. Guimarães, ${ }^{5}$ and B. Rangel ${ }^{7}$ \\ ${ }^{1}$ Department of Fundamental Chemistry, Federal University of Pernambuco, Recife 50740-540, PE, Brazil \\ ${ }^{2}$ Department of Civil Engineering, Federal University of Pernambuco, Recife 50740-540, PE, Brazil \\ ${ }^{3}$ Polytechnic School, University of Pernambuco, Recife 50720-001, PE, Brazil \\ ${ }^{4}$ Department of Civil Construction, Federal University of Paraná, Curitiba 81531-980, PR, Brazil \\ ${ }^{5}$ CONSTRUCT-LFC, Civil Engineering Department, Faculty of Engineering, University of Porto, Porto 4200-465, Portugal \\ ${ }^{6}$ Civil Engineering Department, Pernambuco Catholic University, Pernambuco, Recife 50050-900, Brazil \\ ${ }^{7}$ CONSTRUCT-GEQUALTEC, Civil Engineering Department, Faculty of Engineering, University of Porto, \\ Porto 4200-465, Portugal \\ Correspondence should be addressed to J. M. P. Q. Delgado; jdelgado@fe.up.pt
}

Received 10 July 2020; Revised 2 September 2020; Accepted 19 September 2020; Published 5 October 2020

Academic Editor: Francesco Ruffino

Copyright (C) 2020 R. Berenguer et al. This is an open access article distributed under the Creative Commons Attribution License, which permits unrestricted use, distribution, and reproduction in any medium, provided the original work is properly cited.

\begin{abstract}
The environmental impact of cement production increased significantly in the previous years. For each ton of cement produced, approximately a ton of carbon dioxide is emitted in decarbonation (50\%), clinker furnace combustion (40\%), raw materials transport (5\%), and electricity (5\%). Green strategies have been advanced to reduce it, adding natural or waste materials to substitute components or reinforce the mortar, like fibers or ashes. Sugar cane bagasse ash is a by-product generated from sugar boilers and alcohol factories with capacity to be used in concrete production. Composed mainly of silica, it can be used as mortar and concrete mineral admixture, providing great economic and environmental advantages, particularly in regions with sugar culture and industrial transformation like Brazil. In this research, a study of partial substitution of Portland cement by sugar cane bagasse (SCB) is analyzed, in order to reduce clinker in concrete volume, responsible for high emission of $\mathrm{CO}_{2}$ to the atmosphere. An experimental campaign with cementitious pastes was carried out to evaluate the durability properties' changes due to SCB ash use. Samples containing 15\% of sugarcane bagasse ash unveiled good results in terms of durability, indicating that concrete structure with sugar cane ash research is a new and important scientific topic to be highlighted.
\end{abstract}

\section{Introduction}

In some research centers, concrete's environmental impact is being studied. An environmental impact assessment was investigated by Saffari et al. [1] for Shahrood (Iran) cement, revealing that plant contaminations were identified in air, soil, landscape, and ecology environment. In China, for instance, studies concluded that, in the last decades, the Chinese cement industry has implemented several sustainable strategies in solid wastes and recycling materials have been used in its production [2]. As a result, Hossain et al. evaluated two green strategies to reduce Hong Kong industries' emission of $\mathrm{CO}_{2}$ in cement production: one using glass powder obtained locally from glass bottle waste and the other adding biofuel obtained from local wood waste [3]. Both strategies reduced $12 \%$ of total gases emission and $15 \%$ of energy consumption in cement production [3]. Wilk et al. [4] reported a solution for cement industry to estimate asbestos-cement products' quantity used at polish industry, which is the use of Random Forest algorithm [4]. Aspects of environmental and economic potential of the use of limestone calcined clay cement were investigated in Cuba, comparing it with commercial zeolite cement [5]. The authors concluded that a low amount of $\mathrm{CO}_{2}$ was produced and that it has the potential to be commercialized also in countries where trucks can make $100 \mathrm{~km}$ distance transport from clay deposit to cement plant. 
Recently, advances to improve sustainable cement production were reported [6-14]. Chen et al. [7] employed cements' life cycle impact assessment to ascertain different processes and cement plant variabilities aspects. The results revealed differences between cement production processes in the studied plants set. It was concluded that variations are greater than $40 \%$, mainly due to lack of pollutant content in accurate measurements [7]. This result indicates that studies of green strategies, which are capable of reducing cement production environmental impact, must be pursued. In this sense, Gursel and Ostertag [15] investigated strategies for embodied energy and environmental impacts on reduction of cement usage and aggregate consumption in concrete employed in Singapore. Two cases were considered: (i) the use of materials (cement and aggregate) prepared in Singapore and (ii) the use of materials imported from Malaysia. It was concluded that, using Malaysian cement and aggregates instead of the corresponding Singapore materials, the high-strength concrete potential and embodied energy reduced to $11 \%$ and $31 \%$, respectively.

The effects of by-products' usage and waste materials as supplementary cementitious systems have been also extensively investigated [16-29]. As a result, fly ashes [21, 27], metakaolin [30], geopolymers [31, 32], slags (such as steel slags) $[24,25]$, and sugar cane bagasse ash [33-36] were added to green concrete. The sugar cane bagasse ash is a byproduct resulting from factories' sugar and alcohol boilers [33-36]. Composed mainly of silica $\left(\mathrm{SiO}_{2}\right)$, it can be used as mineral admixture in concrete mortar with great economic and environmental advantages. In this sense, new applications can be destined and provided when waste ashes are incorporated in cement matrices. In particular, the sugar cane bagasse ashes are, in general, discarded, when they could be employed, for example, in the cement-based materials such as concrete and mortars that emit lower levels of $\mathrm{CO}_{2}$ in the atmosphere [37].

This work intends to contribute to the research of partial substitution of Portland cement by sugar cane bagasse (SCB) to reduce the consumption of clinker in concrete volume responsible for high emission of $\mathrm{CO}_{2}$. A new use can be provided when incorporated into cement matrices: the leftovers of bagasse can be used to generate energy and the tailings in concrete and mortars production.

\section{Materials and Methods}

2.1. Materials. This work presents characterization and analyses of sugar cane bagasse ash potential through chemical, physical, and mineralogical methods in order to evaluate its pozzolanicity by direct and indirect techniques. Through accelerated techniques of environmental aggressiveness, the durability of concrete structures with this material is analyzed. Two samples of sugar cane bagasse ash were used:

(i) SCBA-A: collected from a wood oven in a pizzeria in the Metropolitan Region of Recife, Brazil, and used as an energy source and to burn to heat during the pizza cooking (ii) SCBA-B: collected from sugar cane mill located in the city of Palmares, Pernambuco, Brazil, and resulting from sugar derivatives production burning process in heating the boilers

2.2. Materials Characterization. The following techniques were employed in order to characterize physical, chemical, and mineral properties of the SCBA-A and SCBA-B systems to support their rational use and viability to be added in mortar and concrete manufactures: (1) scanning electron microscopy (SEM) analysis, (2) particle size distribution, (3) specific mass, (4) specific area, (5) unit mass, (6) fire loss (FL), and (7) thermogravimetric analysis (TG-DTG). The samples used in characterization and subsequent specimen molding analysis were obtained from the SCBA-A and SCBA-B, dried at $105^{\circ} \mathrm{C}$, and passed through $20 \mathrm{~min}$ sieving process at $70 \mathrm{rpm}$ speed to obtain the passing fraction by opening sieve of $0.075 \mathrm{~mm}$.

The morphology of SCBA-A and SCBA-B was evaluated by scanning electron microscopy (SEM) technique. For morphology analysis, a TESCAN scanning electron microscope (SEM), MIRA3 model, $10 \mathrm{kV}$ voltage, and SE detector (EDS) were used.

2.2.1. Physical Properties. For particle size distribution, a CILAS 1090 laser granulometer was used through dry and wet route. According to the analysis method used, the particle size is given by the respective circumscribe circumference diameter. Thus, rods and particles with long lamellar shape or particle agglomeration are visualized in scanning electron microscopy (SEM) analysis through secondary electron detectors (SE), and the equipment (CILAS 1090 laser granulometer) considers particle length as the diameter, impairing the results analysis.

Portland cement (PC-V), metakaolin (MET), active silica (SIL), fly ash (FA), and sugarcane bagasse ash (SCBA$A$ and SCBA-B) specific mass were determined by the helium gas pycnometer method (recommended by ABNT NBR 16605 [38]), using AccuPyc 1330 V2.01-Micromeritics device. The material specific surfaces were determined using the Blaine Semi-Automatic ACMEL BSA 1 permeability equipment, according to standard NBR 16372 [39].

2.2.2. Chemical Properties. In order to validate the results of muffle fire loss obtained, thermogravimetric tests were employed. The analyses were conducted on STA 449 F3 JUPITER NETZSCH simultaneous analysis equipment. The experimental conditions used were as follows: inert atmosphere $\left(\mathrm{N}_{2}\right)$, maximum flow of $100 \mathrm{ml} / \mathrm{min}$ and heating range of $30^{\circ} \mathrm{C}$ to $1000^{\circ} \mathrm{C}$, with a heating rate of $10^{\circ} \mathrm{C} / \mathrm{min}$, with sample port (alumina crucible), and mass approximately around $20 \mathrm{mg} \pm 0.5$ and purge of $50^{\circ} \mathrm{C} / \mathrm{min}$.

For the chemical analysis of precursor materials, the technique and semiquantitative analysis by X-ray fluorescence (XRF) spectrometry were employed. In this sense, the chemical characterization of the precursor materials was obtained using Shimadzu equipment, model XRF 1800. 


\subsection{Pozzolanicity Experiments}

2.3.1. Direct Method. The water/binders ratio of 0.48 and a mixture of $20 \mathrm{~g}$ of cement with $9.60 \mathrm{~g}$ of water, for the reference material (REF), and $20 \mathrm{~g}$ of cement with $11.04 \mathrm{~g}$ of water and $3 \mathrm{~g}$ of added material, for SCBA-A, SCBA-B, FA, MET, and SIL, were considered. The samples were moulded and after $24 \mathrm{~h}$ were demoulded and added to properly identified submerged cure. Further, the samples were submitted to thermogravimetric analysis with 28,63, and 91 days of age.

On the other hand, the thermogravimetric analyses were performed by using an STA 449 F3 JUPITER NETZSCH analysis equipment. The experimental conditions were as follows: inert atmosphere $\left(\mathrm{N}_{2}\right)$, maximum flow of $100 \mathrm{ml} /$ min, initial heating range of $30^{\circ} \mathrm{C}$ to $1000^{\circ} \mathrm{C}$, with a heating rate of $10^{\circ} \mathrm{C} / \mathrm{min}$, and mass approximately around $20 \mathrm{mg} \pm 0.5$ and purge of $50 \mathrm{C} / \mathrm{min}$. From equations (1) to (6), the chemically combined water content (AQC) related to $\mathrm{C}-\mathrm{S}-\mathrm{H}$ and hydrated aluminate phases formation, calcium hydroxide $\mathrm{Ca}(\mathrm{OH})_{2}$, and calcium carbonate content $\left(\mathrm{CaCO}_{3}\right)$ were calculated:

$$
\begin{aligned}
\mathrm{CH}_{1} & =\frac{\left(\mathrm{H}_{2} \mathrm{O} \times 100\right)}{\mathrm{A}}, \\
\mathrm{CO}_{2} & =\frac{\left(\mathrm{PCO}_{2} \times 100\right)}{\mathrm{B}}, \\
\mathrm{C}_{\mathrm{a}} \mathrm{CO}_{3 \text { real }} & =\mathrm{CO}_{2}-\text { Approx, } \\
\mathrm{CH}_{2} & =\frac{\left(\mathrm{C}_{\mathrm{a}} \mathrm{CO}_{3 \text { real }} \times \mathrm{C}\right)}{100}, \\
\mathrm{AQC} & =\mathrm{AQC}_{\text {total }}-\mathrm{CH}, \\
\mathrm{Ca}(\mathrm{OH})_{2} & =\mathrm{CH}_{1}+\mathrm{CH}_{2},
\end{aligned}
$$

where $\mathrm{H}_{2} \mathrm{O}$ is the water loss that happens in the thermal event of portlandite decomposition, "A" is the molar water mass of $\mathrm{H}_{2} \mathrm{O}, \mathrm{PCO}_{2}$ is the water loss that happens in the thermal decarbonation event, " $\mathrm{B}$ " is the molar mass of the $\mathrm{CO}_{2}$, "Approx." is the approximate $5 \%$ of the carbonate content present in the CP-V ARI, "C" is the molar mass of $\mathrm{Ca}(\mathrm{OH})_{2}$, "AQC total" is the mass loss occurring in the thermal event ranging from 100 to $600^{\circ} \mathrm{C}, \mathrm{CH}_{1}=\mathrm{CH}_{2}$ is the mass loss that occurs in the thermal event ranging from 350 to $450^{\circ} \mathrm{C}$, "AQC" is the chemically combined water, $\mathrm{Ca}(\mathrm{OH})_{2}$ is the total portlandite content, and $\mathrm{CaCO}_{3}$ is the calcium carbonate content.

In addition, the modified Chapelle's method was employed by considering $1 \mathrm{~g}$ of material to evaluate "pozzolanic material" $\left(\mathrm{m}_{2}\right)$ and $2 \mathrm{~g}$ of calcium oxide $\left(\mathrm{m}_{3}\right)$ should be weighed. Immediately thereafter, $250 \mathrm{ml}$ of $\mathrm{CO}_{2}$-free distilled water should be added and measured in an Erlenmeyer flask heated to $90 \pm 5^{\circ} \mathrm{C}$, with stirring in a container simultaneously for $16 \mathrm{~h}$. Subsequently, to test with the pozzolanic material, the same procedures are performed for blank assay containing only calcium oxide determination under the same conditions. Further, $250 \mathrm{ml}$ of sucrose solution was added to Erlenmeyer with material evaluated, "pozzolanic material" and calcium oxide, which was shaken for $15 \mathrm{~min} .50 \mathrm{ml}$ of this solution was pipetted out and titrated with $0.1 \mathrm{M}$ chlorine hydroxide solution using $1 \mathrm{~g} / \mathrm{l}$ of phenolphthalein solution as an indicator. The volume consumed in titration was noted $\left(\mathrm{V}_{2}\right)$. The same procedure was performed with blank assay, noting the volume spent $\left(V_{3}\right)$. The pozzolanic activity index by modifying Chapelle's method can be calculated according to equation (7), corresponding to the amount of calcium hydroxide used (in $\mathrm{mg}$ ) per gram of pozzolanic material:

$$
\mathrm{I}_{\mathrm{Ca}(\mathrm{OH})_{2}}=\frac{28 \times\left(\mathrm{V}_{3}-\mathrm{V}_{2}\right) \times \mathrm{Fc}}{\mathrm{m}_{2}},
$$

where $\mathrm{I}_{\mathrm{Ca}(\mathrm{OH}) 2}$ is the pozzolanic activity index corresponding to the fixed calcium hydroxide content $\left(\mathrm{m}_{1}\right), \mathrm{m}_{2}$ is the pozzolanic material mass $(\mathrm{g}), \mathrm{V}_{2}$ is $\mathrm{HCl} 0.1 \mathrm{M}$ consumed assay with pozzolan solution volume $(\mathrm{ml}), \mathrm{V}_{3}$ is the $\mathrm{HCl}$ $0.1 \mathrm{M}$ consumed in the assay with reference solution volume $(\mathrm{mL})$, and " $\mathrm{Fc}$ " is the $\mathrm{HCl}$ for a concentration of $0.1 \mathrm{M}$ correction factor $(\mathrm{Fc}=1.32)$.

2.3.2. Indirect Method. For the electrical conductivity analysis, the loss of a solution of calcium electrical conductivity hydroxide P.A. was measured, based on the research of Raverdy et al. [40] and Lúxan et al. [41]. In this sense, a 1000-second analysis period was considered to verify sewage sludge ash pozzolanic activity among other supplementary materials. This time interval was fixed as being sufficient to analyze the sugarcane bagasse ashes. In this sense, $1050 \mathrm{ml}$ of distilled water was heated to $60 \pm 2^{\circ} \mathrm{C}$, and this temperature was determined due to similarity with Portland cement hydration initial temperature. After the water reached the ideal temperature and stabilized, $840 \mathrm{mg}$ of $\mathrm{Ca}(\mathrm{OH})_{2}$ P.A. (minimum of $95 \%$ purity) was added. The container was then sealed, and the solution was kept under constant agitation at $700 \mathrm{rpm}$ for a period of 1 hour.

Subsequently, $200 \mathrm{ml}$ of this solution was used and it was transferred to the $250 \mathrm{ml}$ beaker under the same conditions; and rubber stopper was inserted firmly, together with conductivity cell and thermometer. Finally, $4 \mathrm{~g}$ of the studied materials (SCBA-A, SCBA-B, FA, MET, and SIL) was added to the $\mathrm{Ca}(\mathrm{OH})_{2}$ solution, through the appropriate tube fixed to the stopper. Portland cement's performance index in the material pozzolanic activity was determined following part of the physical and chemical requirements proposed by NBR 12653 [42]. According to this standard, minimum physical requirements for a material are considered pozzolanic: a minimum of $90 \%$ performance index with Portland when compared with control.

The material pozzolanic reaction used was evaluated by determining performance index with Portland cement according to NBR 5752 [43]. Two different mortar compositions suggested by the standard were used: (i) mortar A, containing only Portland CP II F-32 cement as binder, and (ii) mortar $\mathrm{B}$, containing $25 \%$ of material analyzed as pozzolanic (SCBA-A and SCBA-B), replacing cement. The materials used in this assay are described in Table 1 . In this 
TABle 1: Determination of pozzolanic activity index with cement.

\begin{tabular}{lcccc}
\hline Materials & \multicolumn{3}{c}{ Mass (g) } & \\
& Mortar A & Mortar B (SCBA-A) & Mortar B (SCBA-B) & Water/binder \\
\hline CP II F-32 & $624 \pm 0.4$ & $468 \pm 0.4$ & $468 \pm 0.4$ & 0.48 \\
Pozzolanic material & - & $156 \pm 0.2$ & $156 \pm 0.2$ & 0.48 \\
Sand normalized by IPT NBR 7214 (2015) & 1872.0 & 1872.0 & 1872.0 & - \\
Water & $300 \pm 0.2$ & $300 \pm 0.2$ & $300 \pm 0.2$ & - \\
\hline
\end{tabular}

sense, six cylindrical specimens with a diameter of $5 \mathrm{~cm}$ $\times$ height of $10 \mathrm{~cm}(5 \mathrm{~cm} \times 10 \mathrm{~cm})$ of mortar moulded for each trace were made and, after 28 days, were ruptured by axial compression according to NBR 5739 [44].

2.4. Durability. The durability tests were performed by considering the following strategies: accelerated carbonation, total absorption, capillarity, and immersion with the objective of efficiency analyses of mineral materials addition. The cylindrical specimens with a diameter of $5 \mathrm{~cm} \times$ height of $10 \mathrm{~cm}(5 \mathrm{~cm} \times 10 \mathrm{~cm})$ were moulded according to NBR 7215 [45]. Using a normal sand described in NBR 7214 [46], the sugarcane bagasse ash from the pizzeria (SCBA-A), the sugarcane bagasse ash from the plant (SCBA-B), the fly ash (FA), the metakaolin (MET), the active silica (SIL), and the Portland CPV-ARI cement (REF) were tested.

The mixture employed in the cylindrical specimen processing was $5 \mathrm{~cm} \times 10 \mathrm{~cm}(1: 3: 0.48)$, that is, $624 \mathrm{~g}$ of cement and $1872 \mathrm{~g}$ of sand with $300 \mathrm{ml}$ of water. Regarding the addition levels, $15 \%$ addition (93.6 $\mathrm{g}$ of mineral) to cement was used for materials used in this research (SCBAA, SCBA-B, FA, MET, and SIL). The choice of $15 \%$ addition is according to Berenguer et al. [37]. Further, 24 specimens were made with $15 \%$ (SCBA-B, FA, MET, and SIL) addition and 6 specimens without mineral addition (references), in which all 30 samples were employed in the accelerated carbonation tests. In addition, 20 specimens were made with $15 \%$ and 5 reference specimens were used in the absorption capillary and immersion assays. Finally, for the analysis of the accelerated migration of chloride ions, 10 specimens with a diameter of $10 \mathrm{~cm} \times$ height of $20 \mathrm{~cm}$ were prepared by considering a ratio of $1: 1.51: 2.06: 0.48$ between cement, sand, and gravel. In addition, the water/ cement ratio with $45 \%$ gravel, $\mathrm{A} \%=10.50, \alpha=0.55$, and cement consumption $\left(\mathrm{kg} / \mathrm{m}^{3}\right)=465.61$ was considered. Among these 10 samples, 8 were samples with mineral additions (SCBA-B, FA, MET, and SIL), and 2 were corresponding to reference systems with absence of mineral additions.

2.4.1. Water Absorption by Capillarity and Immersion. The water absorption tests by capillarity followed the procedures and recommendations of NBR 9779 [47]. It provides mass measurements and water absorption height in mortars. After 28 days of submerged curing, the specimens were packed in an oven in a $45 \pm 2^{\circ} \mathrm{C}$ temperature with internal ventilation until mass constancy for the remaining 23 days to perform the test. A $45 \pm 2^{\circ} \mathrm{C}$ constant temperature was maintained to preserve the integrity of Portland cement hydration products.

In a container installed in an environment with a constant temperature of $23 \pm 2{ }^{\circ} \mathrm{C}$, the specimens were positioned on a metal support, filling the container with water at a constant level of $5 \mathrm{~mm} \pm 1 \mathrm{~mm}$ above the lower face. The saturated mass was determined after $3 \mathrm{~h}, 6 \mathrm{~h}, 24 \mathrm{~h}, 48 \mathrm{~h}$, and $72 \mathrm{~h}$. Previously, the excess water was removed with damp cloth and after each step, it was returned to the container with constant water slide. Then, the experiments were performed on three cylindrical mortar specimens, $5 \mathrm{~cm} \times 10 \mathrm{~cm}$, for each trait described, and the absorption of water by capillarity is calculated according to

$$
A_{\mathrm{w}}=\frac{M_{\mathrm{sat}}-M_{\mathrm{s}}}{S},
$$

where $A_{\mathrm{w}}$ is the water absorption by capillarity $\left(\mathrm{g} / \mathrm{cm}^{2}\right) ; M_{\text {sat }}$ is the saturated mass of the specimen which remains with one of the faces in contact with water for the specified period ( $\mathrm{g}) ; M_{\mathrm{s}}$ is the mass of the dry specimen, as soon as it reaches $23 \pm 2^{\circ} \mathrm{C}$ temperature $(\mathrm{g})$, and $S$ is the cross-sectional area $\left(\mathrm{cm}^{2}\right)$.

According to NBR 9778 [48], samples were taken to an oven for $72 \mathrm{~h}$ at a $45 \pm 2^{\circ} \mathrm{C}$ temperature. According to Berenguer et al. [37], to maintain the Portland cement hydration products' integrity, samples were kept in an oven with internal ventilation until mass constancy for 23 days, with a $45 \pm 2{ }^{\circ} \mathrm{C}$ temperature for later tests. Soon after, dry samples masses were determined and recorded; at the second moment samples were immersed in water at a $(23 \pm 2)^{\circ} \mathrm{C}$ temperature for $72 \mathrm{~h}$, with the aid of hydrostatic scale, and the mass of immersed samples was determined. The assay was performed for each mixture on three cylindrical mortar specimens with $5 \mathrm{~cm} \times 10 \mathrm{~cm}$ and the immersion water absorption was calculated by

$$
A_{\%}=\frac{M_{\mathrm{sat}}-M_{\mathrm{s}}}{M_{\mathrm{s}}} \times 100,
$$

where $M_{\text {sat }}$ is the saturated sample mass after immersion and $M_{\mathrm{s}}$ is the sample dried mass.

2.4.2. Determination of Void Indexes. According to NBR 9778 [48], the total water absorption test enables the calculation of cylindrical specimens void index, $I_{\mathrm{v}}(\%)$. This index is associated with pores total volume accessible to water and does not reflect the easiness with which water can enter the concrete. Thus, the sample void indexes were measured in analyses, according to NBR 9779 (2012) [47]. The mean values calculated in void index test were 
performed for each mixture with three $5 \mathrm{~cm} \times 10 \mathrm{~cm} \mathrm{cy}$ lindrical mortar specimens, according to the following equation:

$$
I_{\mathrm{v}(\%)}=\frac{M_{\mathrm{sat}}-M_{\mathrm{s}}}{M_{\mathrm{sat}}-M_{\mathrm{i}}} \times 100,
$$

where $M_{\mathrm{i}}$ is the immersed saturated sample mass of water, $M_{\text {sat }}$ is the saturated sample after immersion mass, and $M_{\mathrm{s}}$ is the sample dried mass.

2.4.3. Resistance to Accelerated Carbonation. The carbonation camera Caron, which refrigerated $\mathrm{CO}_{2}$ incubator and has automatic digital control of temperature of $\pm 1^{\circ} \mathrm{C}$, relative humidity of $\pm 2 \%$, and controlled $\mathrm{CO}_{2}$ content, was used, as can be seen in Figure 1(a). In this sense, the samples were placed in a dry chamber until they reached constancy of masses (Figure 1(b)) and remained in this environment for 19 days. Because the mass constancy was reached, samples were extracted from the dry chamber and placed in carbonation chamber where they remained for 30 days (Figure 1(c)).

The samples were fractured in three parts each, in which carbonation front verification process was carried out in specimen slices with about $3.3 \mathrm{~cm}$. For rupture of the samples, an EMIC press with a $100 \mathrm{kN}$ maximum capacity was used. The carbonation depth was then measured using a $0.01 \mathrm{~mm}$ precision caliper. The temperature in carbonation chamber was kept constant at temperature of $23^{\circ} \mathrm{C}$, relative humidity of $65 \%$, and $\mathrm{CO}_{2}$ content of $5 \%$. On a regular period, 6 readings were performed in each slice with a chemical solution of phenolphthalein used as a chemical indicator of $\mathrm{pH}$. In preparation of chemical solution and in test performance, the RILEM CPC-18 standard [49], which stipulates a chemical solution of $1 \mathrm{~g}$ of phenolphthalein dissolved in $100 \mathrm{~g}$ of $70 \%$ ethyl alcohol, was considered. After its preparation, phenolphthalein solution was stored in a container for later use. The chemical solution used presented colour change in $\mathrm{pH}$ range between 8.3 and 10.0 presenting with a rosy/crimson red colour. The first rupture was performed immediately after 1 month, and the carbonation front advance was measured. The second rupture was performed after 2 months of samples confinement in the carbonation chamber, as shown in Figure 2.

2.4.4. Accelerated Chloride Ion Migration. The standard test method for electrical indication of the concrete's ability to resist chloride ion penetration $\left(\mathrm{Cl}^{-}\right)$was based on ASTM C1202 standard [50]. In this sense, in the present article, the tests of accelerated chloride ion migration were performed by considering 365-day-old samples. The tests were performed with the application of a $60 \mathrm{~V}$ voltage over 6 hours with the passing current every 30 -minute measurement. The passing current Amps readings in seconds over time generated a curve. The test result was the integral representing the area between the curve and the axis, obtained from passing the load over 6 hours in A/s or Coulombs (C). The specimens were dried in an oven at $100^{\circ} \mathrm{C}$ until mass constancy; then, they were packed for 24 hours in a dry chamber to cool down. At the second moment, protection systems (coating) were applied to one of the circular faces of each specimen with silicone layer on its side. Finally, a saturation method was applied by vacuum and immersion. In the cathodic chamber, an aqueous solution with $3 \% \mathrm{NaCl}$ was placed, and in the anodic chamber, a solution of $\mathrm{NaOH}$ $0.3 \mathrm{~N}$ was placed. In addition, the samples (REF, SCBA, FA, MET, and SIL) with a diameter of $100 \mathrm{~mm}$ and a height $50 \mathrm{~mm}$ and 365 days of submerged curing were positioned between two cells (Figure 3), negative and positive, containing solutions of sodium chloride (3\% by mass) and sodium hydroxide $(0.3 \mathrm{~N})$, respectively. They were subjected to a potential difference of $60 \mathrm{~V}$ for a period of 6 hours.

The applied voltage to a $0.1 \Omega$ resistor was checked every $30 \mathrm{~min}$. Therefore, the electric current (Ohm's law) and, consequently, the passing load through equation (11) according to ASTM C1202 [50] were calculated. For each mixture of the different samples, electrical loads were calculated by arithmetic mean of two determinations in different specimens:

$$
\mathrm{Q}=\mathrm{KC} / \mathrm{A}\left(I_{0}+2 I_{30}+2 I_{60}+\cdots+2 I_{300}+2 I_{330}+2 I_{360}\right) \text {, }
$$

where $Q$ is the electric charge; $K \mathrm{C} / \mathrm{A}$ is the constant equal to $900 \mathrm{C} / \mathrm{A}$ and $l_{\mathrm{n}}$ is the electric current after applying the voltage.

\section{Results and Discussion}

3.1. Characterizations. The XRF experiments revealed a large predominance of the chemical compositions of $\mathrm{CaO}$, $\mathrm{SiO}_{2}, \mathrm{Fe}_{2} \mathrm{O}_{3}, \mathrm{Al}_{2} \mathrm{O}_{3}, \mathrm{MgO}$, and $\mathrm{K}_{2} \mathrm{O}$ for the precursor materials employed, where for Portland cement samples (REF) the XRF data for these oxide compounds were $62 \%, 22 \%, 4 \%$, $4 \%, 2 \%$, and $0.4 \%$, respectively. In this sense, for the SCBCA$\mathrm{A}$, the corresponding values were $7 \%, 44 \%, 3 \%, 2 \%, 5 \%$, and $7 \%$, respectively. For the SCBA-B, these values were 3\%, $71 \%, 2 \%, 5 \%, 2 \%$, and $3 \%$, respectively. For the FA samples, compositions of $2 \%, 70 \%, 5 \%, 17 \%, 0.8 \%$, and $2 \%$ were obtained, respectively, for $\mathrm{CaO}, \mathrm{SiO}_{2}, \mathrm{Fe}_{2} \mathrm{O}_{3}, \mathrm{Al}_{2} \mathrm{O}_{3}, \mathrm{MgO}$, and $\mathrm{K}_{2} \mathrm{O}$ compounds. In addition, for the MET samples, the corresponding values were $0.1 \%, 64 \%, 3 \%, 28 \%, 1 \%$, and $3 \%$, respectively. For the SIL samples, the corresponding chemical compositions were $0.3 \%, 96 \%, 0.8 \%, 0.1 \%, 0.5 \%$, and $1 \%$, respectively.

On the other hand, the tests of particle distributions, specific masses determinations, specific materials surface areas, materials unit masses, and loss to fire are shown in Table 2.

According to particle size distribution analysis, Portland cement grains (PCV) revealed results for medium particles distribution, with diameter at $50 \%\left(\mathrm{D}_{50}\right)$ equal to $5.90 \mu \mathrm{m}$, while SCBA-A, SCBA-B, FA, MET, and SIL presented the average diameters equal to $8.25 \mu \mathrm{m}, 10.32 \mu \mathrm{m}, 9.76 \mu \mathrm{m}$, $5.72 \mu \mathrm{m}$, and $63.67 \mu \mathrm{m}$, respectively. To bestow these results, electron microscopy scanning technique was used to ascertain the shape and values of particles found in 

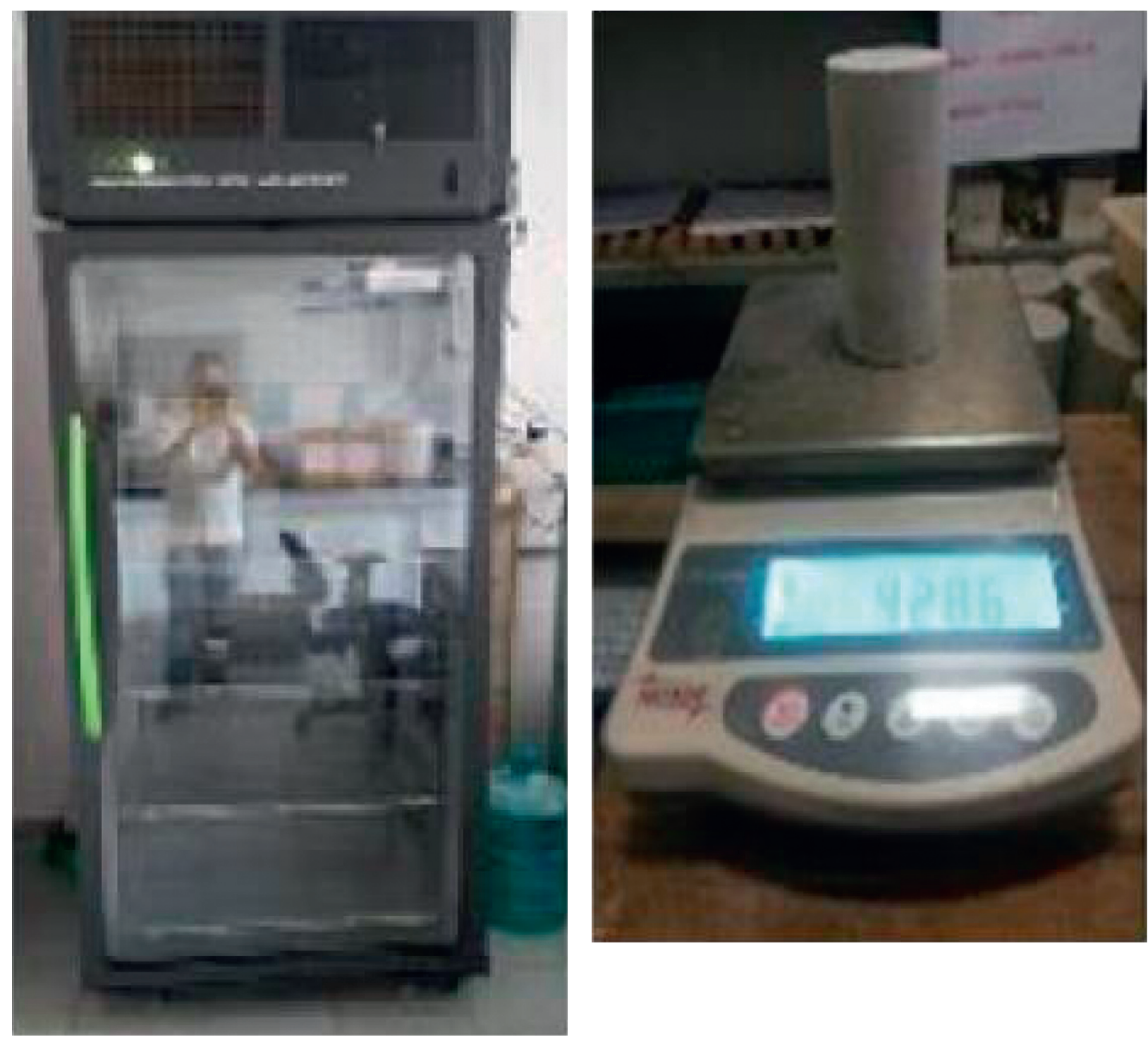

(a)

(b)

Figure 1: Continued. 


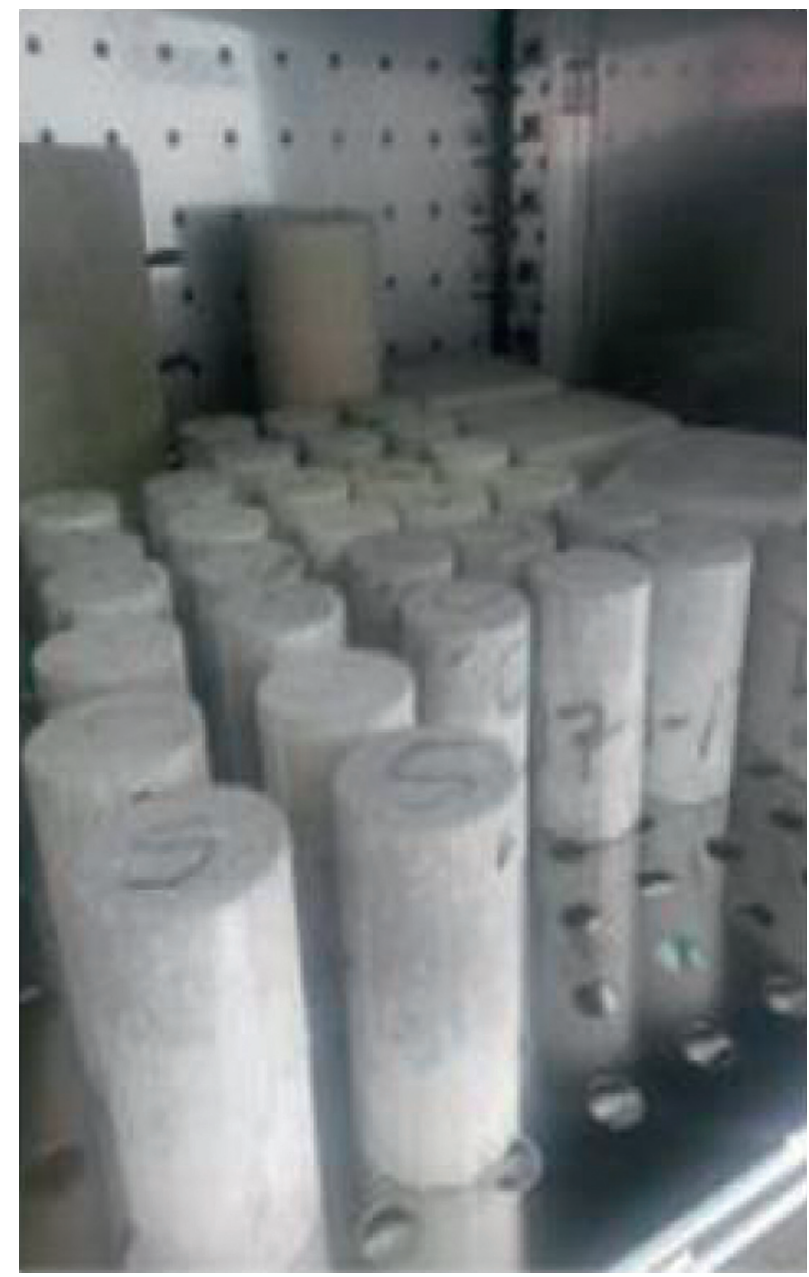

(c)

FIGURE 1: (a) Carbonation chamber; (b) measurement for mass constancy; (c) carbonation chamber with specimens.

granulometry. In this sense, Figure 4 shows microstructural differences between SCBA-A and SCBA-B systems from SEM/EDS analyses.

On the other hand, for the estimated accuracy of fire loss test, the validation was made according to NBR NM 18 [51] and results were compared with mass loss obtained by thermogravimetry. Table 2 shows the values of six fire loss determinations, 6.37\%, 19.89\%, 13.64\%, 2.03\%, 3.07, and $3.09 \%$, for samples (CP-V, SCBA-A, SCBA-B, FA, MET, and SIL), respectively. By thermogravimetry assay, mass loss at the approximate temperature of $1000^{\circ} \mathrm{C}$ was $6.08 \%, 22.22 \%$, $11.65 \%, 1.34,2.63$, and $2.98 \%$, respectively. The difference between values achieved by the two techniques was only $0.29 \%, 2.33 \%, 1.99 \%, 0.69 \%, 0.44 \%$, and $0.11 \%$ for each sample. It can be concluded that the fire loss test was significantly accurate and presents an excellent correlation $\left(R^{2}=0.9756\right)$, as shown in Figure 5, with thermogravimetric analysis results presented in Figure 6.

On the other hand, from Figure 6 , it is possible to verify the mass loss occurring in respective thermal events, particularly highlighted thermal events happening between $400^{\circ} \mathrm{C}$ and $450^{\circ} \mathrm{C}$ with portlandite decomposition.
Therefore, thermogravimetry was the analytical technique used to monitor possible pozzolanic reactions of cement pastes containing 15\% ash addition (SCBA-A and SCBAB). Dweck et al. [52] employed thermogravimetric analysis in Portland cement pastes and revealed that it is possible to determine the chemically combined water content of all hydrated compounds in a thermal event ranging from $50^{\circ} \mathrm{C}$ to portlandite final decomposition temperature. Thus, studies were performed through reference pastes thermoanalysis (without SCBA) and in pastes containing SCBA-A or SCBA-B. The samples were analyzed by thermogravimetry after 28,63 , and 91 days of cure identifying hydrated phases formed, together with observing possible consumption of Portlandite reactions with sugarcane bagasse ash. According to Hoppe Filho et al. [53], it is possible to observe the characteristics of each phase in thermal events. In addition, Table 3 and Figure 7 show data of chemically combined water and portlandite $\left(\mathrm{AQC}\right.$ and $\left.\mathrm{Ca}(\mathrm{OH})_{2}\right)$.

Through the $\Delta H>0$ and exothermic $\Delta H<0$ endothermic structural transformations, it was possible to perform a quantitative analysis [54]. Thus, analyses were 


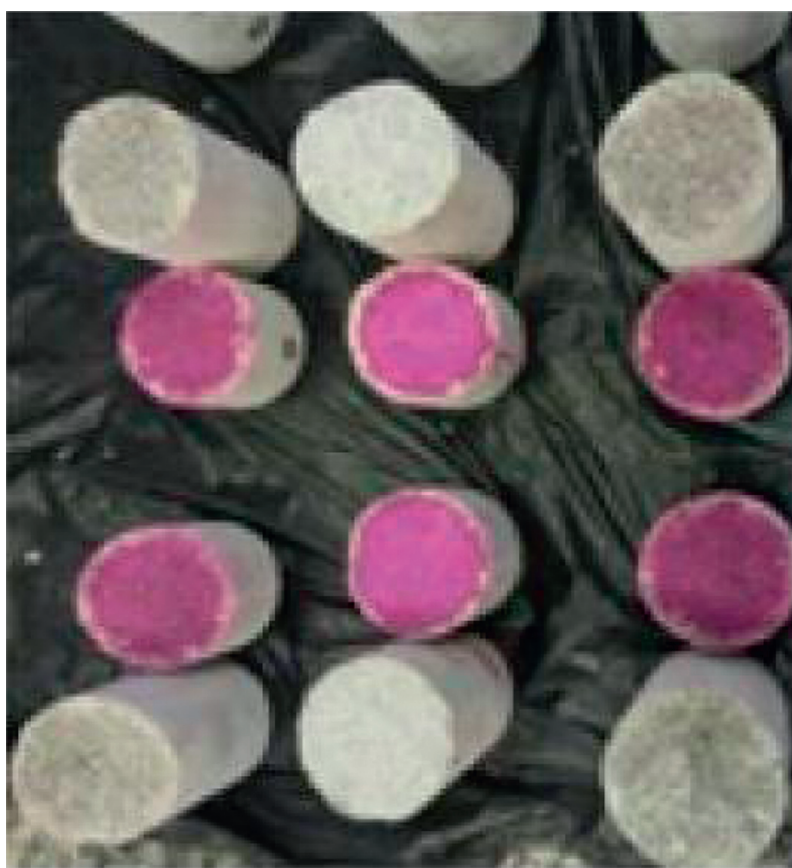

(a)

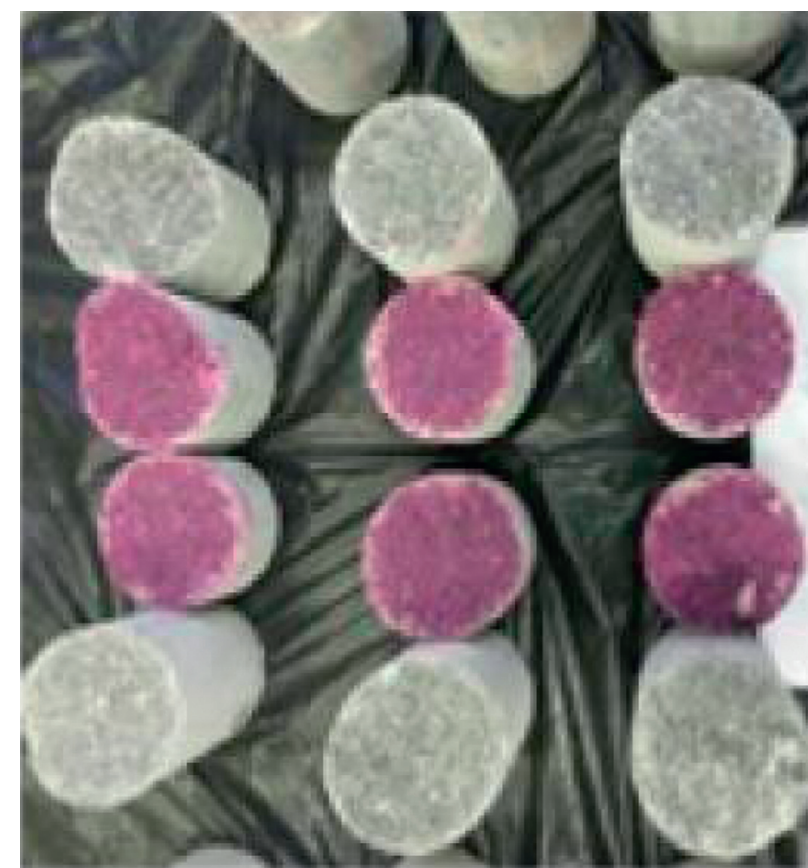

(b)

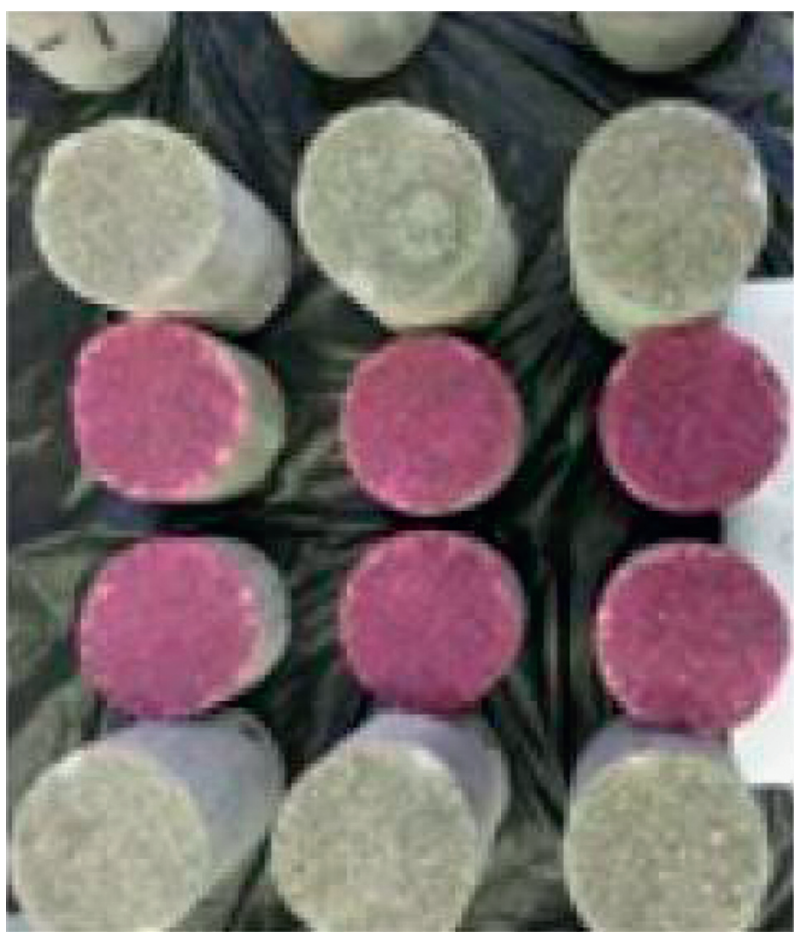

(c)

FIGURE 2: Samples after testing for carbonation evaluation: (a) reference; (b) fly ash; (c) active silica.

made in pastes at 28, 63, and 91 days through stochiometric calculations and quantifying contents of hydrated compounds formed, with portlandite content remaining in hydrated matrix and calcium carbonate content.

From Figure 7, the paste thermogravimetric analysis results of the chemically combined water content (AQC) can be associated with the C-S-H formation and hydrated aluminate phases, calcium hydroxide $\left(\mathrm{Ca}(\mathrm{OH})_{2}\right)$ and calcium carbonate content $\left(\mathrm{CaCO}_{3}\right)$, which were quantified through equations (1)-(6). Table 3 shows the results after stochiometric calculations of hydrated compounds analyzed.

According to Hoppe Filho et al. [53], the cement hydration evolution provides an increase in portlandite phase $\left(\mathrm{Ca}(\mathrm{OH})_{2}\right)$, as well as in chemically combined water content (AQC), due to hydration of anhydrous phases $\mathrm{C}_{3} \mathrm{~A}, \mathrm{C}_{3} \mathrm{~S}, \mathrm{C}_{2} \mathrm{~S}$, and $\mathrm{C}_{4} \mathrm{AF}$, as can be seen in Table 3 and Figure 6. For 


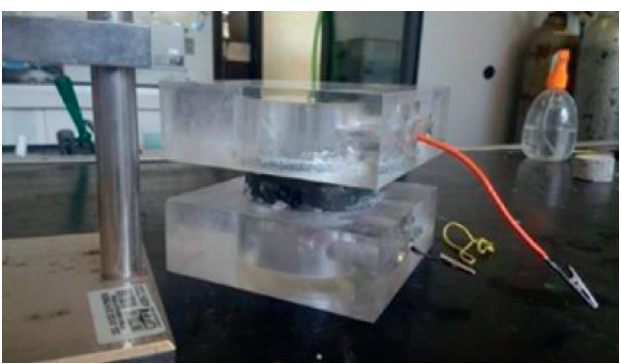

(a)

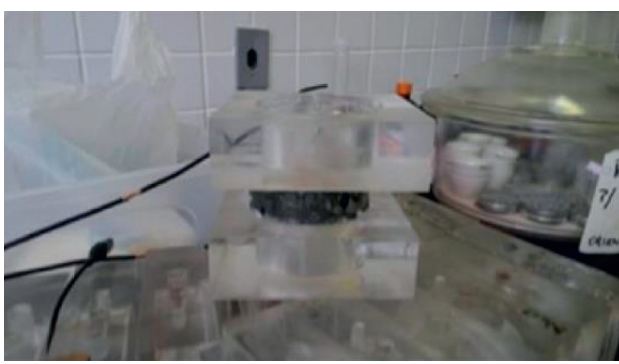

(b)

FIGURE 3: Cells for chloride migration assay and chloride migration assay preparation.

TABLE 2: Summary of the materials characterization.

\begin{tabular}{|c|c|c|c|c|c|c|}
\hline Properties & Cement & SCBA-A & SCBA-B & FA & MET & SIL \\
\hline Unit mass $\left(\mathrm{kg} / \mathrm{dm}^{3}\right)$ & 1.00 & 0.075 & 0.089 & 0.693 & 0.703 & 0.550 \\
\hline Specific mass $\left(\mathrm{kg} / \mathrm{dm}^{3}\right)$ & 3.17 & 2.72 & 2.37 & 2.39 & 2.81 & 2.22 \\
\hline Specific surface area $\left(\mathrm{m}^{2} / \mathrm{g}\right)$ (Blaine Electronic) & 0.452 & 0.655 & 0.654 & 0.678 & 0.474 & 0.718 \\
\hline Specific surface area $\left(\mathrm{m}^{2} / \mathrm{g}\right)(\mathrm{BET})$ & 1.784 & 5.461 & 22.849 & 1.158 & 16.908 & 20.341 \\
\hline Particle distribution $\mathrm{D}_{10}, \mu \mathrm{m}$ & 0.94 & 0.21 & 0.94 & 0.18 & 0.34 & 2.99 \\
\hline Particle distribution $\mathrm{D}_{50}, \mu \mathrm{m}$ & 5.90 & 8.25 & 10.32 & 9.76 & 5.72 & 63.67 \\
\hline Particle distribution $D_{90}, \mu \mathrm{m}$ & 29.15 & 43.95 & 43.28 & 92.30 & 34.36 & 372.00 \\
\hline Mass loss, \% (TG) & 6.08 & 22.22 & 11.65 & 1.34 & 2.63 & 2.98 \\
\hline Fire loss, \% (FL) & 6.37 & 19.89 & 13.64 & 2.03 & 3.07 & 3.09 \\
\hline
\end{tabular}
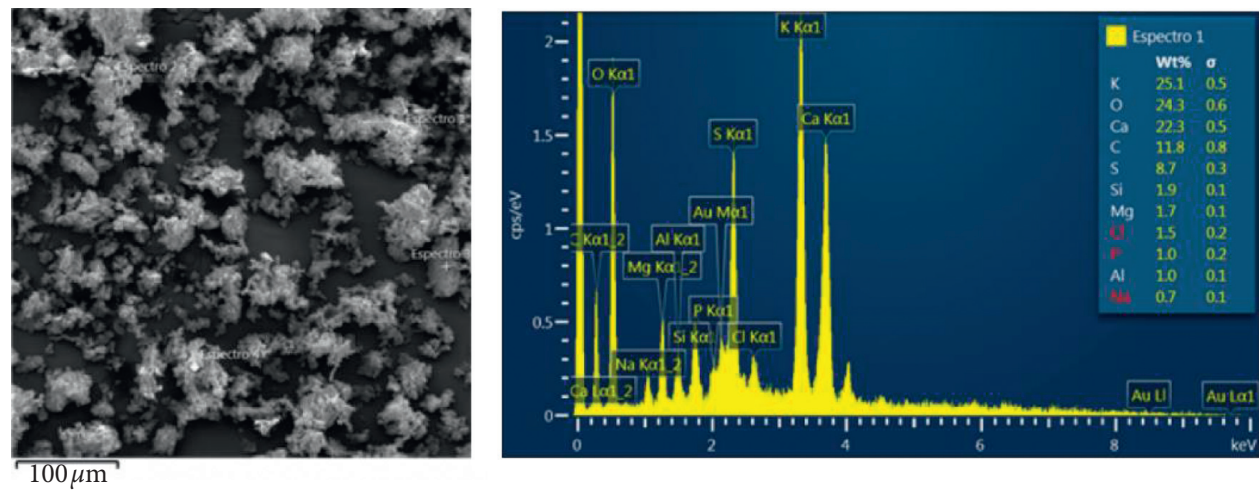

(a)
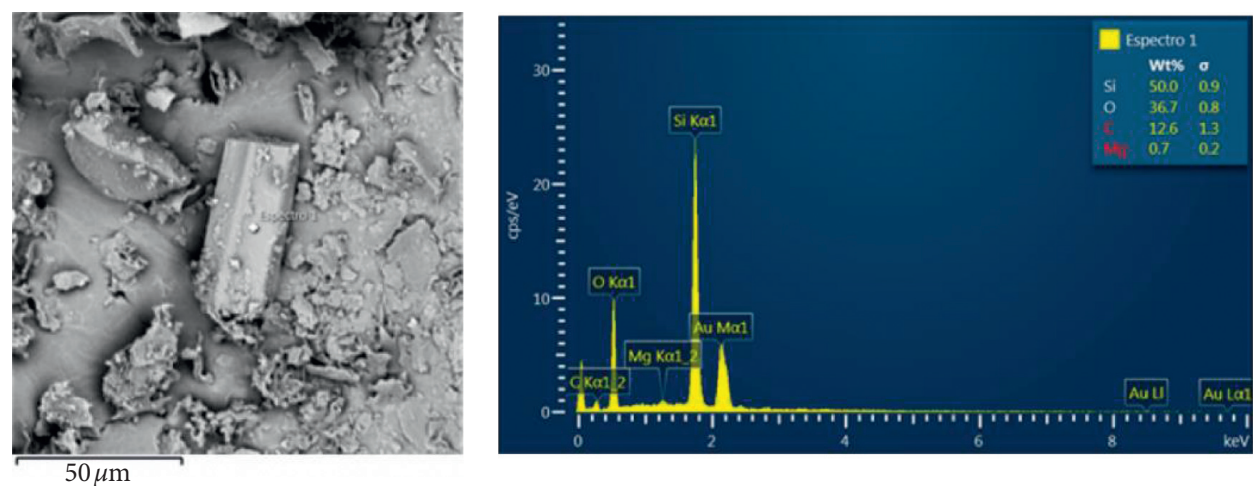

(b)

FIgure 4: Scanning electron microscopy-EDS detector of (a) SCBA-A and (b) SCBA-B. 


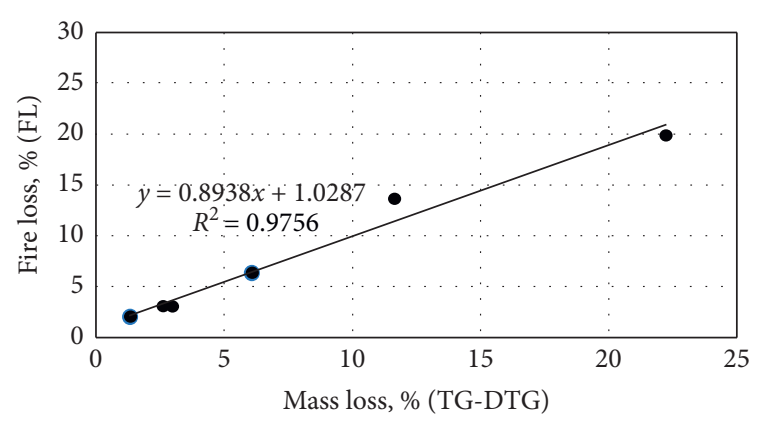

FIgURE 5: Fire loss (FL) versus mass loss (TG).

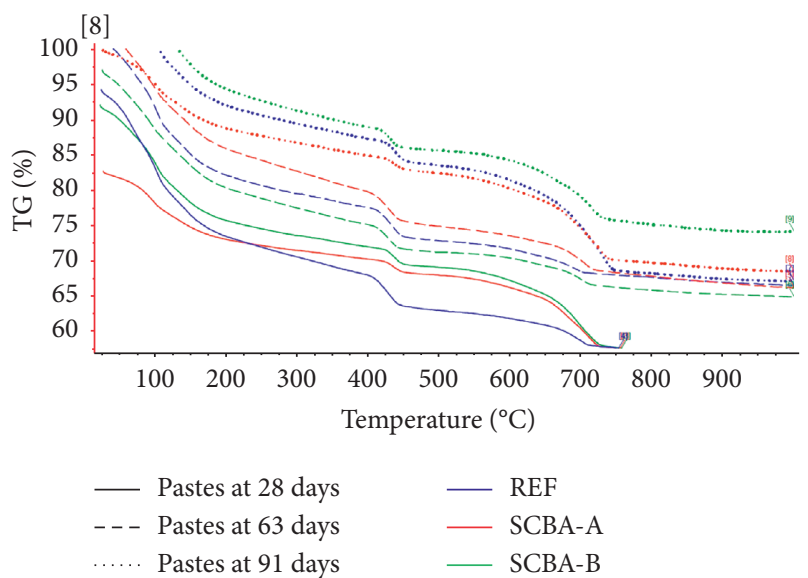

Figure 6: Thermogravimetric analysis (TG/DTG) of the pastes at 28, 63, and 91 days.

reference sample hydrated compounds (NDF) analysis contents, no significant evolution was perceived, as the results remained almost constant. When analyzing the event that occurred between $400^{\circ} \mathrm{C}$ and $450^{\circ} \mathrm{C}$, the hypothesis of portlandite decomposition $\left(\mathrm{Ca}(\mathrm{OH})_{2}\right)$ can be attributed, since there was an evolution in portlandite increase for reference samples (CP V ARI). In calcium carbonate content analysis event, it is possible to observe at 91 days a significant increase described in Table 3, revealing that a sample carbonation may have occurred, which is suitable for other generating sources. For samples (SCBA-A and SCBA-B), the contents of hydrated compounds (AQC) analyses which increased in these compounds were observed over time in a discrete but noticeable way as shown in Figure 6. Regarding portlandite content $\left(\mathrm{Ca}(\mathrm{OH})_{2}\right)$, the samples containing $15 \%$ ash became quite expressive in quantitative terms for both samples. It can suggest that ash as the main action, the nucleation hypothesis, is a source that generates portlandite. On the other hand, if (AQC) evolution and $\left(\mathrm{Ca}(\mathrm{OH})_{2}\right)$ consumption became noticeable according to Figure 5, this trend confirmed the hypothesis of pozzolanic reactions of the samples in the paste. In this sense, ashes (SCBA-A and SCBA-B) may have acted through pozzolanic reaction in microstructure refinement, due to the fact that secondary C-S-H crystals decrease the pore diameter average of cement matrix, and are associated with filler effect.

Figure 7 also shows chemically combined water content (2C) and portlandite content in pastes studied at 91 days of hydration, obtained by thermogravimetry. Both are related to Portland cement hydration and are influenced by pozzolanic reaction occurrence in cement paste.

The increase in AQC content and the reduction of portlandite content of series with sugarcane bagasse ash related to reference series indicate that addition presented a higher amount of C-S-H. This occurred due to consumption of typical portlandite of pozzolanic reaction.

3.2. Pozzolanic Activities by the Direct Method. According to Hoppe Filhoet al. [53] and to NBR 15895 [55], the modified Chapelle's method can be employed to evaluate the kinetics of pozzolanic reaction in pozzolan/lime system. At the beginning of the essay, during the samples chemical reactions, the samples' vitreous fraction was gradually solubilized by actions of hydroxyl ions, which react with calcium ions to hydrates precipitation [56]. However, according to the results presented in Table 4, there is an indication that SCBA-A has a lower value than the minimum pozzolanic activity index suggested by Raverdy et al. [40]. In addition, SCBA-B ash presented results slightly above pozzolanic activity minimum value index. Therefore, it is possible to conclude that the increase in pozzolanic activity is associated with amorphous material amount considering other samples also with the same characteristics, specific surface area, as well as the change from quartz- $\alpha$ to quartz- $\beta$.

It is noteworthy that NBR 15895 [55] does not define the minimum value for $\mathrm{I}_{\mathrm{Ca}(\mathrm{OH}) 2}$ through Chapelle's test; however, French standard NFP 18-513 [57] brings a minimum pozzolanic activity value of $700 \mathrm{mg}$ of $\mathrm{Ca}(\mathrm{OH})_{2} / \mathrm{g}$ pozzolan, which indicates that samples SCBA-A, SCBA-B, and FA do not fit as pozzolanic material for this test. Following Raverdy et al.'s [40] suggestion, at a minimum value of $330 \mathrm{mg}$ of $\mathrm{Ca}(\mathrm{OH})_{2} / \mathrm{g}$, the only sample that could not fit would be the SCBA-A. There is a possibility that values below the minimum established by the same authors in the SCBA-A samples may be related to their respective calcination temperatures, due to the direct influence on pozzolanic reactions when calcination temperatures are different from $600^{\circ} \mathrm{C}$.

3.3. Pozzolanic Activities by the Indirect Method. The data of electrical conductivity of the sugarcane bagasse ash (SCBAA and SCBA-B), fly ash (AF), metakaolin (MET), and active silica (SIL) are shown in Figure 8.

From Figure 8, except for the fly wheel ash exception (Figure 8(c)), there was a drop in electrical conductivity over time after insertion of these materials, indicating a pozzolanic potential for all samples. Regarding fly ash considered as exception sample, Payá et al. [58] observed the behavior for measurements up to 1000 seconds, where there was conductivity, but virtually no conductivity was observed in longer times (10000 seconds). Regarding metakaolin and active silica (Figures $8(\mathrm{~d})$ and $8(\mathrm{e})$ ), it was observed that conductivity is sharply reduced in the test's first 20 seconds, and after this period it continues to fall in a slower manner. On the other hand, all samples showed an initial drop in the first twenty seconds. 
TABLE 3: Summary of chemically combined water and portlandite (AQC and $\mathrm{Ca}(\mathrm{OH})_{2}$ ).

\begin{tabular}{|c|c|c|c|c|c|c|c|}
\hline Cement paste & Cure & AQC (\%) & $\mathrm{H}_{2} \mathrm{O}(\%)$ (mass loss) & $\mathrm{Ca}(\mathrm{OH})_{2}$ & $\mathrm{CO}_{2}(\%)$ (mass loss) & $\mathrm{CaCO}_{3 \text { real }}$ & Residual mass \\
\hline Cement CP V ARI & & 10.69 & 3.26 & 17.28 & 3.91 & 2.56 & 73.46 \\
\hline SCBA-A & 28 days & 10.28 & 1.89 & 25.00 & 10.69 & 19.30 & 73.12 \\
\hline SCBA-B & & 10.73 & 1.90 & 21.42 & 8.66 & 14.68 & 72.85 \\
\hline Cement CP V ARI & & 10.70 & 3.61 & 19.48 & 4.30 & 3.31 & 71.03 \\
\hline SCBA-A & 63 days & 13.11 & 3.59 & 25.29 & 5.26 & 7.23 & 71.84 \\
\hline SCBA-B & & 10.96 & 2.80 & 18.37 & 3.87 & 3.80 & 75.74 \\
\hline Cement CP V ARI & & 10.83 & 2.49 & 24.86 & 11.75 & 17.70 & 68.10 \\
\hline SCBA-A & 91 days & 13.11 & 1.69 & 23.54 & 10.62 & 24.14 & 68.59 \\
\hline SCBA-B & & 11.67 & 1.85 & 17.66 & 6.59 & 9.97 & 72.66 \\
\hline
\end{tabular}

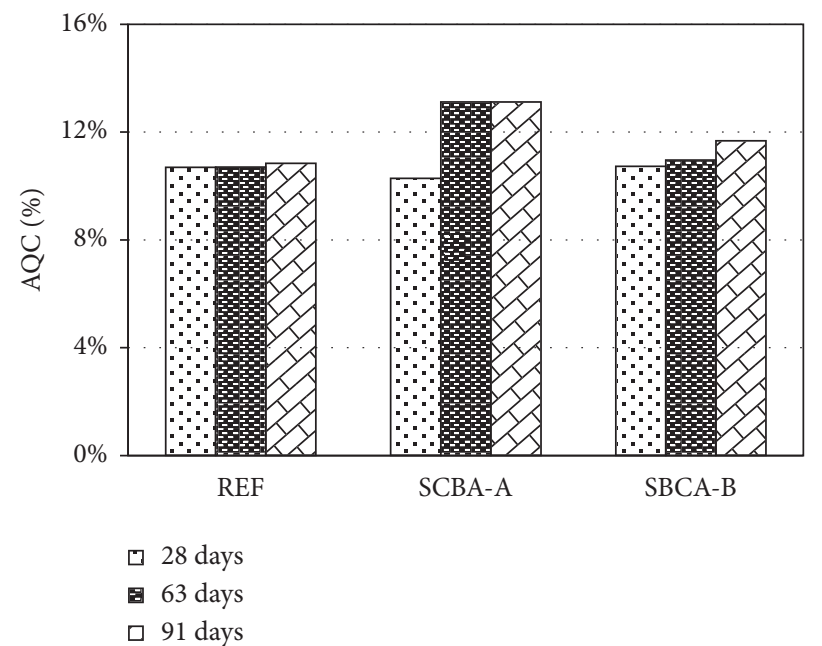

(a)

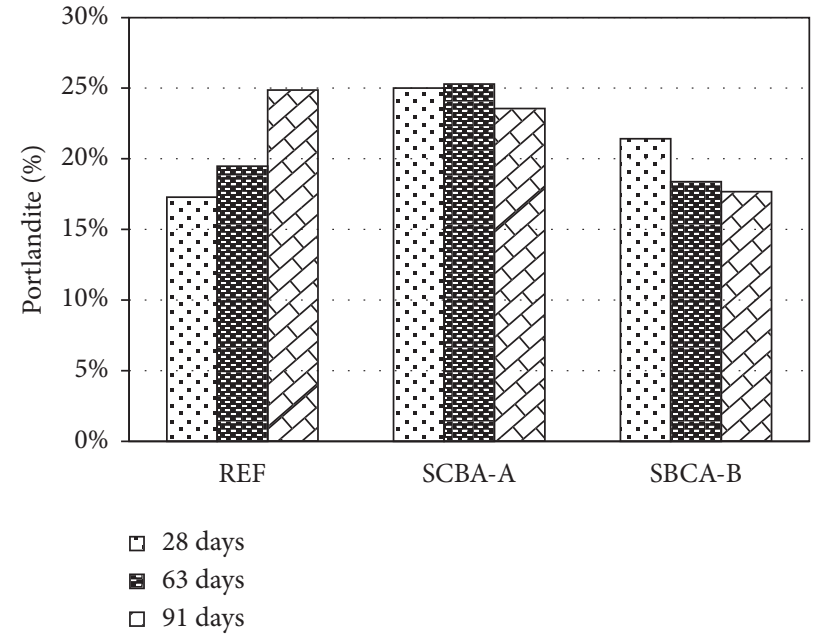

(b)

FIgURE 7: Chemically combined water content (AQC) and portlandite $\left(\mathrm{Ca}(\mathrm{OH})_{2}\right)$.

TABle 4: Data of modified Chapelle's method for all mineral additions.

\begin{tabular}{lccrrr}
\hline & SCBA-A & SCBA-B & FA & MET & SIL \\
\hline $\mathrm{ICa}(\mathrm{OH})_{2} \mathrm{mg} \mathrm{CaO} / \mathrm{g}$ modified Chapelle's method & 293 & 337 & 382 & 1194 & 1503 \\
\hline
\end{tabular}

The electrical results showed that the essay up to $1000 \mathrm{~s}$ was sufficient concerning conductivity loss, attributing it to pozzolanic reactions hypothesis. In addition, Table 5 shows the variation values between initial conductivity and final conductivity for each time, $100 \mathrm{~s}$ and $1000 \mathrm{~s}$. At the end, the conductivity loss percentage for a given time interval is determined, and this value is dependent of the reaction temperature and water, calcium hydroxide, and pozzolan ratio contained in the solution.

From Figure 8(e), the calcium hydroxide is quickly consumed, followed by direct metakaolin competitor (Figure $8(\mathrm{~d})$ ). In addition, the active silica and metakaolin obtained large loss of conductivities when compared with other samples in two times analyzed, $100 \mathrm{~s}$ and $1000 \mathrm{~s}$, seemingly due to the super pozzolanic material. In addition, the results of fly ash samples (Figure 8(c)) corroborate those reported by Payá et al. [58]. It was also verified that for fly ash results up to 1000 seconds did not significantly express the entire fly ash pozzolanic potential, being necessary to extrapolate to times equal to or greater than 10000 seconds, as suggested. From Table 5, the corresponding values of $\%$ PRCond 1000 , for $\Delta 1000$ equal to or greater than 1.22 , reveal a conductivity loss equal to $37.91 \%$ and $23.96 \%$, respectively.

3.4. Durability Aspects. Table 6 shows the values of absorption by immersion and voids index, as well as the values of void indices, carbonation depth, passing charge, and chloride depth for all types of concrete considered in this article.

From Table 6, the reference samples exhibited larger behavior of absorption, in which the samples of silica fume obtained the lowest water absorption values. In this sense, samples with sugarcane bagasse ash have acceptable results throughout the tests. This test provided information on how much each sample absorbed water being immersed for 72 continuous hours, as well as the voids index and specific mass of each specimen. In addition, the void indices' values 


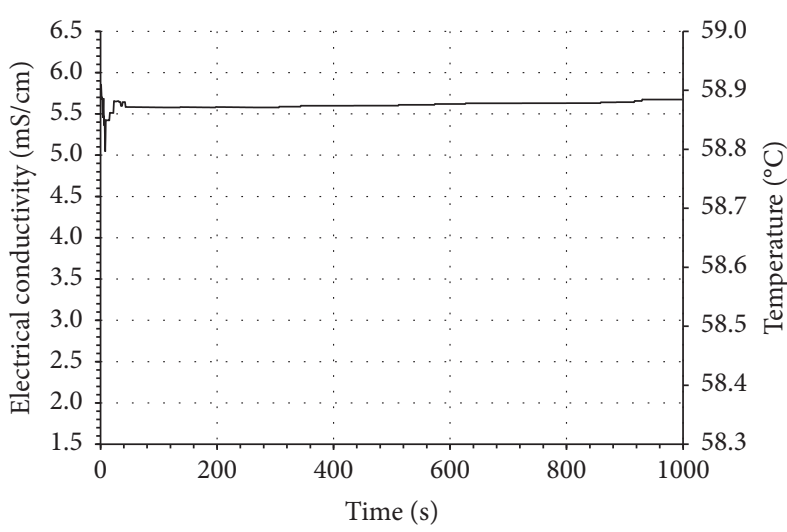

(a)

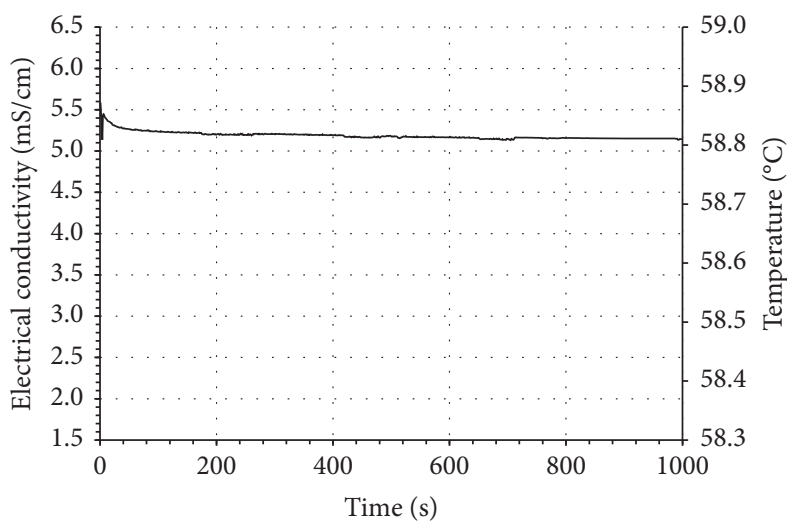

(c)

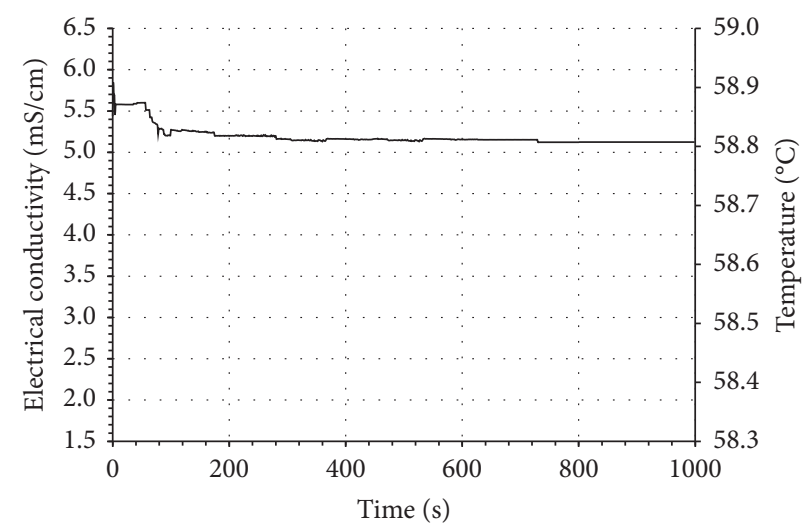

(b)

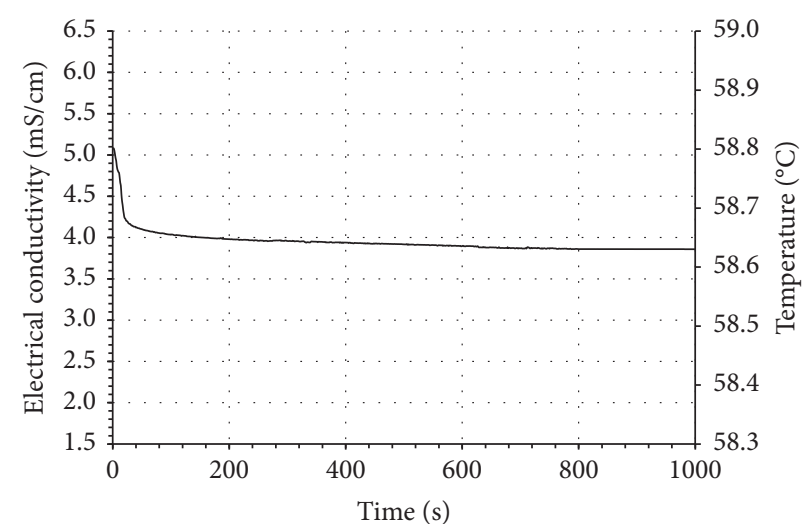

(d)

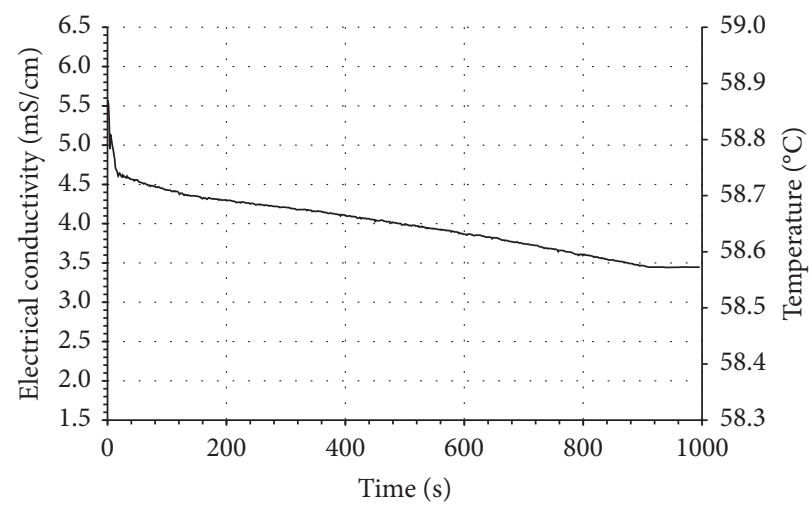

(e)

FIGURE 8: Electrical conductivity of (a) SCBA-A ash, (b) SCBA-B ash, (c) fly ash, (d) metakaolin, and (e) active silica.

TABLE 5: Summary of electrical conductivity and performance indices.

\begin{tabular}{|c|c|c|c|}
\hline \multirow{2}{*}{ Samples } & \multicolumn{2}{|c|}{ Electrical conductivity } & \multirow{2}{*}{ Performance index with Portland cement (\%) } \\
\hline & $\Delta_{100}$ & $\Delta_{1000}$ & \\
\hline REF & - & - & 100 \\
\hline SCBA-A & 0.11 & 0.16 & 93 \\
\hline SCBA-B & 0.22 & 0.30 & 98 \\
\hline FA & 0.33 & 0.42 & - \\
\hline MET & 1.04 & 1.22 & - \\
\hline SIL & 1.14 & 2.10 & - \\
\hline
\end{tabular}


TABLE 6: Data of the durability analyses.

\begin{tabular}{lccccc}
\hline Samples & Absorption by immersion (\%) & Void indexes (\%) & Carbonation depth $(\mathrm{mm})$ & Passing charge $(\mathrm{C})$ & Chloride depth (mm) \\
\hline REF & 7.39 & 15.58 & 4.7 & 3036 & 12.7 \\
SCBA-B & 7.16 & 15.22 & 6.2 & 1800 & 9.2 \\
FA & 7.34 & 15.67 & 4.9 & 506 & 5.9 \\
MET & 7.20 & 15.36 & - & 1076 & 3.9 \\
SIL & 6.03 & 12.94 & 2.5 & 86 & 3.3 \\
\hline
\end{tabular}

of the reference samples were larger when compared with the other systems, especially when the silica fume is employed and when the lowest void indices were verified. In the samples of silica fume, some chemical reactions occur with the refinement of the pores, leading to a physical effect, that is, a filler effect. The samples with ash from the sugarcane bagasse $\mathrm{CBC}$ revealed satisfactory results, where the SCBA-B presented a lower mean void index when compared with fly ash samples.

On the other hand, for the ability of the materials to resist the carbonation processes, after the first rupture, it was possible to observe that the sugar cane bagasse ash specimens showed less depth of carbonation when compared with the active silica specimens. For specimens with fly ash addition, the carbonation progress was observed at some points that were larger than the reference samples. By considering the second rupture of the samples, the trends of the advance of the carbonation front obtained a uniform continuity, being observed that the samples with active silica obtained their values of the advance of the carbonation front at 63 days in $2.5 \mathrm{~mm}$, for the samples containing fly ash obtained an advance of $4.9 \mathrm{~mm}$, followed by ashes from the $6.2 \mathrm{~mm}$ sugarcane bagasse. The contribution of the carbonation depth values as a function of the precursor materials shown, in the thermogravimetric analyses, a significant quantity of carbonates for the SCBA-B and FA samples. Therefore, the samples containing the sugarcane bagasse ash seemingly are more suitable to react with the $\mathrm{CO}_{2}$ molecules, allowing the advance on the carbonation front. However, regarding the results of the carbonation front, all results were promising with the depths of the carbonation front varying between $2.5 \mathrm{~mm}$ and $6.2 \mathrm{~mm}$. Regarding the natural exposure, the mineral additions incorporated in this article were favorable to the durability of the concrete. Besides, according to ASTM C1202 [50], the reference samples (REF) obtained a moderate classification as an evaluation criterion, the SCBA-B samples obtained a low classification, and samples containing the addition of fly ash (FA) and metakaolin (MET) obtained a very low classification, in relation to the samples with the addition of active silica (SIL), which stood out with an insignificant classification and with a passing electric charge of $86 \mathrm{C}$.

From the perspective of durability associated with the resistance to chloride ions, from Table 6 , a reduction in the depth of penetration with the use of mineral additions was observed; that is, all samples containing mineral additions obtained values less than $10 \mathrm{~mm}$. However, the reference material presented the largest depth of penetration $(12.7 \mathrm{~mm})$, being the material more suitable to react with chloride ions.

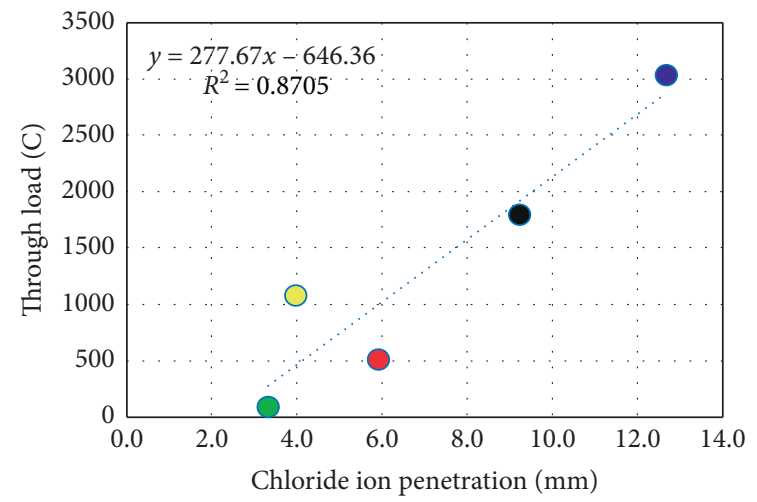

Figure 9: Linear regression analysis between the parameters of through load and depth of penetration of chloride ions.

The phenomenon of attack on reinforced concrete structures by chloride ions can be considered as a complex phenomenon due to the wide range of possible interactions between the ions and the pores of the solid; also the chloride ions also can react with hydrated phases and nanosystems present in the material [59-62]. It is also noted that the samples with mineral additions (SCBA-B) are shown as a promising material in terms of durability to resist deterioration via chloride ions. In addition, Figure 9 shows the linear regression analysis between the throughput and depth of penetration of chloride ions, where there is a considerable correlation $\left(R^{2}=0.8705\right)$ between the parameters of through load and depth of penetration of chloride ions.

Finally, from the sustainability perspective, the reuse of the supplementary material SCBA-B can be useful because this material is often discarded, and significant results are obtained when compared with more popular mineral additions of samples contributing to the sustainability and preservation of natural resources.

\section{Conclusions}

With the analyses and results obtained, it is possible to conclude the following:

(i) Mineral addition improved concrete's properties, improving mechanical properties, refining capillary pores, and so forth. In view of pozzolanic determination analyses' results, in sugarcane bagasse samples, SCBA-A and SCBA-B, it was observed that, in some trials, SCBA-A was considered as a pozzolanic material, but in other analyses it was considered to have low reactivity, not reaching the minimum expected. 
(ii) SCBA-A and SCBA-B samples did not have any type of processing (besides being dried and sifted in the $0.075 \mathrm{~mm}$ opening sieve), although results revealed that sugarcane bagasse ash SCBA-A can be considered as a low-pozzolanicity material. It is possible to be used as a pozzolanic material with some improvements, such as calcination and grinding, increasing its specific surface area and reactivity. Sugarcane bagasse ash SCBA-B samples were considered as medium reactivity pozzolanic material, because in analyses and assays performed the obtained results were higher than or close to the minimum of expected performance, becoming susceptible to be used as mineral addition.

(iii) Therefore, it can be concluded that there is no evident correlation between accelerated methods (modified Chapelle's and electrical conductivity) used during this research. However, in relation to nonaccelerated methods, some techniques presented a good correlation.

(iv) With SCBA-B obtaining satisfactory results, it becomes possible to use it, maintaining the same conditions of research with proportions of $15 \%$ addition.

(v) From the durability perspective, samples with $15 \%$ of sugarcane bagasse ash showed good results. Likewise, it is important to highlight that, despite some satisfactory initial results obtained, the mortar and concrete durability analyses require further research on structures' durability when sugarcane bagasse ash is added.

(vi) The phenomena that occurred during the pozzolanic reaction were complex, making it difficult to determine the reactivity of a given material, so it is only possible to identify general trends of its behavior.

Sugarcane bagasse ash has today its end in dumps; adding it to cement matrix is one more step to give concrete industry an opportunity to raise its sustainable responsibility and enhance cement performance.

\section{Data Availability}

Data are available upon request to the corresponding author.

\section{Conflicts of Interest}

The authors declare that there are no conflicts of interest regarding the publication of this paper.

\section{Acknowledgments}

This work was supported by the following: base funding, UIDB/04708/2020, and programmatic funding, UIDP/ 04708/2020, of the CONSTRUCT-Instituto de I\&D em Estruturas e Construções. It was also funded by national funds through the FCT/MCTES (PIDDAC) and CNPq, CAPES, and FINEP (Brazilian Research Agencies). The authors also acknowledge the L'Oréal-UNESCO-ABC "For Women in Science."

\section{References}

[1] A. Saffari, M. Ataei, F. Sereshki, and M. Naderi, "Environmental impact assessment (EIA) by using the Fuzzy Delphi Folchi (FDF) method (case study: Shahrood cement plant, Iran)," Environment, Development and Sustainability, vol. 21, no. 2, pp. 817-860, 2019.

[2] W. Shen, Y. Liu, B. Yan et al., "Cement industry of China: driving force, environment impact and sustainable development," Renewable and Sustainable Energy Reviews, vol. 75, pp. 618-628, 2017.

[3] M. U. Hossain, C. S. Poon, I. M. C. Lo, and J. C. P. Cheng, "Comparative LCA on using waste materials in the cement industry: a Hong Kong case study," Resources, Conservation and Recycling, vol. 120, pp. 199-208, 2017.

[4] E. Wilk, M. Krówczyńska, and B. Zagajewski, "Modelling the spatial distribution of asbestos-cement products in Poland with the use of the random forest algorithm," Sustainability, vol. 11, no. 16, p. 4355, 2019.

[5] S. Sánchez Berriel, A. Favier, E. Rosa Domínguez et al., "Assessing the environmental and economic potential of limestone calcined clay cement in Cuba," Journal of Cleaner Production, vol. 124, pp. 361-369, 2016.

[6] A. Shirkhani, H. Kouchaki-Penchah, and A. AzmoodehMishamandani, "Environmental and exergetic impacts of cement production: a case study," Environmental Progress \& Sustainable Energy, vol. 37, no. 6, pp. 2042-2049, 2018.

[7] C. Chen, G. Habert, Y. Bouzidi, and A. Jullien, "Environmental impact of cement production: detail of the different processes and cement plant variability evaluation," Journal of Cleaner Production, vol. 18, no. 5, pp. 478-485, 2010.

[8] S. A. Miller and R. J. Myers, "Environmental impacts of alternative cement binders," Environmental Science \& Technology, vol. 54, no. 2, pp. 677-686, 2020.

[9] M. U. Hossain, C. S. Poon, Y. H. Dong, and D. Xuan, "Evaluation of environmental impact distribution methods for supplementary cementitious materials," Renewable and Sustainable Energy Reviews, vol. 82, pp. 597-608, 2018.

[10] A. Sagastume Gutiérrez, J. J. Cabello Eras, C. A. Gaviria, J. Van Caneghem, and C. Vandecasteele, "Improved selection of the functional unit in environmental impact assessment of cement," Journal of Cleaner Production, vol. 168, pp. 463-473, 2017.

[11] D. Song, J. Yang, B. Chen, T. Hayat, and A. Alsaedi, "Life-cycle environmental impact analysis of a typical cement production chain," Applied Energy, vol. 164, pp. 916-923, 2016.

[12] I. Vázquez-Rowe, K. Ziegler-Rodriguez, J. Laso, I. Quispe, R. Aldaco, and R. Kahhat, "Production of cement in Peru: understanding carbon-related environmental impacts and their policy implications," Resources, Conservation and Recycling, vol. 142, pp. 283-292, 2019.

[13] M. Wu, Y. Zhang, Y. Ji et al., "Reducing environmental impacts and carbon emissions: study of effects of superfine cement particles on blended cement containing high volume mineral admixtures," Journal of Cleaner Production, vol. 196, pp. 358-369, 2018.

[14] S. Z. Carvalho, F. Vernilli, B. Almeida, M. D. Oliveira, and S. N. Silva, "Reducing environmental impacts: the use of basic oxygen furnace slag in portland cement," Journal of Cleaner Production, vol. 172, pp. 385-390, 2018. 
[15] A. P. Gursel and C. P. Ostertag, "Impact of Singapore's importers on life-cycle assessment of concrete," Journal of Cleaner Production, vol. 118, pp. 140-150, 2016.

[16] P. Xu, Q. Zhao, W. Qiu, Y. Xue, and N. Li, "Microstructure and strength of alkali-activated bricks containing municipal solid waste incineration (MSWI) fly ash developed as construction materials," Sustainability, vol. 11, no. 5, p. 1283, 2019.

[17] J. Szulej, P. Ogrodnik, and B. Klimek, "Zeolite tuff and recycled ceramic sanitary ware aggregate in production of concrete," Sustainability, vol. 11, no. 6, pp. 1782-1816, 2019.

[18] M. Singh, K. Choudhary, A. Srivastava, K. Singh Sangwan, and D. Bhunia, "A study on environmental and economic impacts of using waste marble powder in concrete," Journal of Building Engineering, vol. 13, pp. 87-95, 2017.

[19] S. Ruan and C. Unluer, "Influence of supplementary cementitious materials on the performance and environmental impacts of reactive magnesia cement concrete," Journal of Cleaner Production, vol. 159, pp. 62-73, 2017.

[20] S. Sakir, S. N. Raman, M. Safiuddin, A. B. M. A. Kaish, and A. A. Mutalib, "Utilization of by-products and wastes as supplementary cementitious materials in structural mortar for sustainable construction," Sustainability, vol. 12, no. 9, p. 3888, 2020.

[21] T. Y. Huang, P. T. Chiueh, and S. L. Lo, "Life-cycle environmental and cost impacts of reusing fly ash," Resources, Conservation and Recycling, vol. 123, pp. 255-260, 2017.

[22] W.-J. Long, D. Zheng, H.-b. Duan, N. Han, and F. Xing, "Performance enhancement and environmental impact of cement composites containing graphene oxide with recycled fine aggregates," Journal of Cleaner Production, vol. 194, pp. 193-202, 2018.

[23] G. K. Warati, M. M. Darwish, F. F. Feyessa, and T. Ghebrab, "Suitability of scoria as fine aggregate and its effect on the properties of concrete," Sustainability, vol. 11, no. 17, p. 4647, 2019.

[24] Y. Kim, A. Hanif, M. Usman, M. J. Munir, S. M. S. Kazmi, and S. Kim, "Slag waste incorporation in high early strength concrete as cement replacement: environmental impact and influence on hydration \& durability attributes," Journal of Cleaner Production, vol. 172, pp. 3056-3065, 2018.

[25] T. Nguyen, H. Mai, D. Phan, and D. Nguyen, "Responses of concrete using steel slag as coarse aggregate replacement under splitting and flexure," Sustainability, vol. 12, 2020.

[26] M. Sofi, Y. Sabri, Z. Zhou, and P. Mendis, "Transforming municipal solid waste into construction materials," Sustainability, vol. 11, no. 9, pp. 2661-2722, 2019.

[27] H.-J. Chen, N.-H. Shih, C.-H. Wu, and S.-K. Lin, "Effects of the loss on ignition of fly ash on the properties of high-volume fly ash concrete," Sustainability, vol. 11, no. 9, p. 2704, 2019.

[28] N. M. Azmee and N. Shafiq, "Investigating the impacts of ultra-fine calcium carbonate in high-volume fly ash concrete for structural rehabilitation for sustainable development," Sustainability, vol. 11, 2019.

[29] S. Pushkar, "The effect of different concrete designs on the lifecycle assessment of the environmental impacts of concretes containing furnace bottom-ash instead of sand," Sustainability, vol. 11, no. 15, p. 4083, 2019.

[30] E.-J. Elizondo-Martinez, P. Tataranni, J. Rodriguez-Hernandez, and D. Castro-Fresno, "Physical and mechanical characterization of sustainable and innovative porous concrete for urban pavements containing metakaolin," Sustainability, vol. 12, no. 10, p. 4243, 2020.
[31] G. Araya-Letelier, P. Maturana, M. Carrasco, F. C. Antico, and M. S. Gómez, "Mechanical-damage behavior of mortars reinforced with recycled polypropylene fibers," Sustainability, vol. 11, no. 8, p. 2200, 2019.

[32] C. Parra, E. M. Sánchez, I. Miñano, F. Benito, and P. Hidalgo, "Recycled plastic and cork waste for structural lightweight concrete production," Sustainability, vol. 11, no. 7, pp. 1876-1915, 2019.

[33] E. Arif, M. W. Clark, and N. Lake, "Sugar cane bagasse ash from a high-efficiency co-generation boiler as filler in concrete," Construction and Building Materials, vol. 151, pp. 692-703, 2017.

[34] R. G. D. Molin Filho, D. A. Longhi, R. C. T. d. Souza, R. D. Vanderlei, P. R. Paraíso, and L. M. d. M. Jorge, "Study of the compressive and tensile strenghts of self-compacting concrete with sugarcane bagasse ash," Revista IBRACON de Estruturas e Materiais, vol. 12, no. 4, pp. 874-883, 2019.

[35] J. P. Moretti, S. Nunes, and A. Sales, "Self-compacting concrete incorporating sugarcane bagasse ash," Construction and Building Materials, vol. 172, pp. 635-649, 2018.

[36] S. Singh, R.N., G. D. Ransinchung, S. Debbarma, and P. Kumar, "Utilization of reclaimed asphalt pavement aggregates containing waste from sugarcane mill for production of concrete mixes," Journal of Cleaner Production, vol. 174, pp. 42-52, 2018.

[37] R. A. Berenguer, A. P. B. Capraro, M. H. F. de Medeiros, A. M. P. Carneiro, and R. A. De Oliveira, "Sugar cane bagasse ash as a partial substitute of Portland cement: effect on mechanical properties and emission of carbon dioxide," Journal of Environmental Chemical Engineering, vol. 8, no. 2, p. 103655, 2020.

[38] ABNT NBR 16605: 2017, "Portland cement and other powdered material-determination of the specific gravity," 2020, https://www.abntcatalogo.com.br/norma.aspx?ID=372002.

[39] ABNT NBR 16372: 2015, "Portland cement and other powdered materials-determination of fineness by the air permeability method (Blaine method)," 2020, https://www. abntcatalogo.com.br/norma.aspx? ID=332676.

[40] M. Raverdy, F. Brivot, A. M. Paillere, and R. Bron, "Appréciation de l'activité pouzzolanique de constituents secondaires," in Proceedings of the 7e Congrés International de la Chimie des Ciments, pp. 36-41, Paris, France, 1980.

[41] M. P. Luxán, F. Madruga, and J. Saavedra, "Rapid evaluation of pozzolanic activity of natural products by conductivity measurement," Cement and Concrete Research, vol. 19, no. 1, pp. 63-68, 1989.

[42] ABNT NBR 12653:2014, Pozzolanic materials-requirements, 2020, http://www.consorciobradesco.com.br/.

[43] ABNT NBR 5752: 2014, "Pozzolanic materials-determination of the performance index with Portland cement at 28 days," 2020, https://www.abntcatalogo.com.br/norma.aspx? $\mathrm{ID}=315344$.

[44] ABNT NBR 5739:2018, Concrete-compression test of cylindrical specimens, 2020, https://www.abntcatalogo.com.br/ norma.aspx?ID=398444.

[45] ABNT NBR 7215:2019, Portland cement-determination of compressive strength of cylindrical test specimens, 2020, https://www.abntcatalogo.com.br/norma.aspx?ID=413557.

[46] ABNT NBR 7214:2015, Standard sand for cement testsspecification, 2020, https://www.abntcatalogo.com.br/norma. aspx?ID=348035.

[47] ABNT NBR 9779:2012, Mortar and hardened concrete-determination of water absorption by capillarity, 2020, https://www.abntcatalogo.com.br/norma.aspx?ID=193710. 
[48] ABNT NBR 9778:2009 Hardened mortar and concrete-determination of absorption, voids and specific gravity, 2020, https://www.abntcatalogo.com.br/norma.aspx?ID=52163.

[49] R. T. 56-MHM, "CPC-18 Measurement of hardened concrete carbonation depth," Materials and Structures, vol. 21, pp. 453-455, 1988.

[50] ASTM C1202-19 test method for electrical indication of concretes ability to resist chloride ion penetration, 2020, http://astm.org/Standards/C1202.

[51] NBR NM 18, "Portland cement-chemical anlysis-determination of loss on ignition," 2012, https://www.abntcatalogo. com.br/norma.aspx? $\mathrm{ID}=91002$.

[52] J. Dweck, A. L. Cherem da Cunha, C. A. Pinto, J. Pereira Gonçalves, and P. M. Büchler, "Thermogravimetry on calcined mass basis-hydrated cement phases and pozzolanic activity quantitative analysis," Journal of Thermal Analysis and Calorimetry, vol. 97, no. 1, pp. 85-89, 2009.

[53] J. Hoppe Filho, A. Gobbi, E. Pereira, V. A. Quarcioni, and M. H. F. d. Medeiros, "Atividade pozolânica de adições minerais para cimento Portland (Parte I): Índice de atividade pozolânica (IAP) com cal, difração de raios-X (DRX), termogravimetria (TG/DTG) e Chapelle modificado," Matéria (Rio de Janeiro), vol. 22, no. 3, 2017.

[54] A. M. Betioli, J. Hoppe Filho, M. A. Cincotto, P. J. P. Gleize, and R. G. Pileggi, "Chemical interaction between EVA and Portland cement hydration at early-age," Construction and Building Materials, vol. 23, no. 11, pp. 3332-3336, 2009.

[55] ABNT NBR 15895:2010, Pozzolanic materials-determination of calcium hydroxide fi xed-modified Chapelle's method, 2020, https://www.abntcatalogo.com.br/norma.aspx? ID $=80644$.

[56] M. H. F. Medeiros, J. H. Filho, and P. Helene, "Influence of the slice position on chloride migration tests for concrete in marine conditions," Marine Structures, vol. 22, no. 2, pp. 128-141, 2009.

[57] E. Ferraz, "Pozzolanic activity of metakaolins by the French standard of the modified Chapelle test: a direct methology," Acta Geodynamica et Geomaterialia, vol. 12, no. 3179, pp. 289-298, 2015.

[58] J. Payá, M. V. Borrachero, J. Monzó, E. Peris-Mora, and F. Amahjour, "Enhanced conductivity measurement techniques for evaluation of fly ash pozzolanic activity," Cement and Concrete Research, vol. 31, no. 1, pp. 41-49, 2001.

[59] X. Liu, B. Ma, H. Tan et al., "Effect of aluminum sulfate on the hydration of Portland cement, tricalcium silicate and tricalcium aluminate," Construction and Building Materials, vol. 232, Article ID 117179, 2020.

[60] X. Liu, B. Ma, H. Tan et al., "Effects of colloidal nano- $\mathrm{SiO}_{2}$ on the immobilization of chloride ions in cement-fly ash system," Cement and Concrete Composites, vol. 110, Article ID 103596, 2020.

[61] X. Liu, B. Ma, H. Tan et al., "Chloride immobilization of cement-based material containing nano- $\mathrm{Al}_{2} \mathrm{O}_{3}$," Construction and Building Materials, vol. 220, pp. 43-52, 2019.

[62] X. Liu, B. Ma, H. Tan, L. Gao, and P. Chen, "Improvement in chloride immobilization of cement-metakaolin system by triisopropanolamine," Applied Clay Science, vol. 193, Article ID 105656, 2020. 